\title{
K ZÁKLADNÝM ATRIBÚTOM VÝTVARNEJ POETIKY PETRA ČANECKÉHO SO ZAMERANÍM SA NA INSCENÁCIE V RÉŽII ROMANA POLÁKA
}

\author{
NORA NAGYOVÁ \\ Divadelná fakulta Vysokej školy múzických umení v Bratislave
}

\begin{abstract}
Abstrakt: Štúdia upriamuje pozornost̉ na základné atribúty poetiky Petra Čaneckého, významného predstavitela slovenského kostýmového výtvarníctva. Autorka sa koncentruje na inscenácie, ktoré vytvoril v spolupráci so svojím dlhoročným kolegom, režisérom Romanom Polákom, a na príklade vybraných inscenácií sa snaží pomenovat’ a popísat principiálne znaky Čaneckého poetiky.

Klúčové slová: divadelný kostým, výtvarná poetika, divadelná réžia, herectvo, Peter Čanecký, Roman Polák
\end{abstract}

„Človek je človeku nepretržite objektom. “1 Túto myšlienku francúzskeho filozofa Jeana-Paula Sartra citoval kostýmový výtvarník Peter Čanecký vo svojej habilitačnej prednáške s názvom Cit a vedomie v kostýmovej tvorbe. Človek podl’a neho disponuje schopnostami pretvárat’ a menit’ svet, ktorý nielen vnímame, ale naň aj emocionálne reagujeme. ${ }^{2}$ Záujem o človeka možno považovał’ za jeden z hlavných atribútov, ktorý Čaneckého motivoval k výberu celoživotného povolania. Ako sám konštatuje, divadelný kostým sa pre neho stal partnerom, prostredníctvom ktorého sa môže permanentne vzdelávat’ a uvažovat’ v širších súvislostiach. Zároveň ho považuje za nástroj napomáhajúci mu mysliet’ a cítit’ v kontinuite s dramatickým textom. ${ }^{3}$ Uvažovanie o divadelnom kostýme sa u neho neustále dostáva do konfrontácie s otázkami zmeny identity, modifikácie či maskovania.

V jeho výtvarnej poetike je zrejmá tendencia $\mathrm{k}$ minimalistickému stvárneniu, ktorá sa prejavuje najmä vo farebnej a štýlovej striedmosti achromatického kolorovania (tj. škála farieb biela - sivá - čierna). O minimalistickom stvárnení môžeme hovorit aj v súvislosti s historickými a folklórnymi kostýmami, kde eliminuje ornamentálne prvky a zároveň sa snaží o zachovanie autentických strihov. Za d’alší príznačný atribút Čaneckého poetiky sa dá považovat’ štylizácia, ktorá nadobúda rôzne modifikované podoby (napr. deformácia smerujúca ku karikovaniu postáv a pod.).

Výtvarný rukopis Petra Čaneckého sa kontinuálne vyvíjal. V minulosti dominovala $\mathrm{v}$ jeho výtvarných návrhoch plne kolorovaná kresba, no postupne prechádzal k exaktnej, čistej linke, vo väčšine prípadov už bez využitia farebnosti. Tu je dôležité pripomenút', že Čanecký nevníma výtvarné návrhy ako umelecké diela a nepokladá za potrebné ich vystavovat’ v rámci výstav. Dôvodom je unikátnost' divadelného oka-

${ }^{1}$ ČANECKÝ, P. Cit a vedomie v kostýmovej tvorbe. In ŠTEFKO, V. (ed). Prednášky o divadle. Bratislava : Vysoká škola múzických umení a Divadelný ústav, s. 189.

${ }^{2}$ Tamže.

${ }^{3}$ Tamže. 
mihu, ktorý považuje za neprenosný. Kostýmové návrhy označuje za dôležitý prostriedok pri komunikácii s režisérom a hereckými predstavitelmi, ale predovšetkým s pracovníkmi divadelných dielní. Aj preto k nim prikladá konkrétne ukážky odevných materiálov, z ktorých by mal byt kostým zhotovený. Vždy pripravuje návrhy pre všetky varianty predpokladaných javiskových situácií a hereckého obsadenia. Zvolený prístup nabáda Čaneckého mysliet’ pri navrhovaní kostýmu na konkrétnych nositelov (hercov, herečky). Tento prístup úzko súvisí s vyjadrením divadelnej teoretičky Colette Conroy, podl’a ktorej sa človek „učí kreslit rozpoznatelnú l’udskú podobu nie tak, že kreslí to, čo vidí, ale tak, že spoznáva konvencie, vd’aka ktorým môže telo zobrazit"“4 Peter Čanecký sa pri kreovaní kostýmu snaží využit’ aj fyzické a osobnostné dispozície hercov/herečiek, pochopit’ vnútornú podstatu konkrétneho hereckého stvárnenia: „Tvár herca - občianska i umelecká - je súčast’ou záujmu kostýmovej tvorby. Spolu s telesným zjavom herca má svoje rozmery, objemnost’ a proporcionálnost'. Je schopná byt’ výrazom bytosti, jej mimiky, gesta a pohybu. ${ }^{\text {}}{ }$

Spolupráca s Romanom Polákom poskytla Petrovi Čaneckému nové možnosti, odvíjajúce sa od originálnych režijných interpretácí́. Medzi oboma tvorcami dlhodobo dochádza k súladu, podmienenému kontinuálnou spoluprácou a nepochybne aj osobnou dôverou. Čanecký vníma Poláka ako režiséra, ktorý vidí v obrazoch to, čo ostatní režiséri nevidia. Porozumenie so spolutvorcom a zdiel'anie spoločného jazyka považuje výtvarník za dôležitý predpoklad nielen správneho fungovania divadelnej inscenácie, ale aj dlhodobej umeleckej spolupráce. ${ }^{6}$

\section{Achromatická farebnost'}

Už sme naznačili, že $\mathrm{k}$ charakteristickým znakom poetiky Petra Čaneckého patrí farebná a štýlová striedmost’ vyplývajúca z achromatickej farebnosti. Za d’alší z nich môžeme označit výtvarníkovo úsilie ladit’ jednotlivé elementy kostýmu do celku spájajúceho rozmanité tóny určitého spektra farieb. Táto harmonizácia sa pre recipienta stáva črtou, vd’aka ktorej si Čaneckého rukopis zapamätá, a to napriek tomu, že podobný prvok možno nájst’ aj u iných kostýmových výtvarníkov a výtvarníčok (najmä u Marije Havran). Achromatická farebnost’ otvára priestor pre invenčnú prácu s l’udskou siluetou, ked’že sterilné farebné riešenie dáva intenzívnejšie vyniknút detailom.

V tomto duchu pojal Peter Čanecký napríklad kostýmy k inscenácii Anna Kareninová (Slovenské národné divadlo, 2009), ktorá vznikla na základe dramatizácie rovnomenného románu Leva Nikolajeviča Tolstého. Roman Polák ju ako jednu z troch ním režírovaných inscenáciii ${ }^{7}$ reflektoval v habilitačnej prednáške s názvom Obsah a forma niektorých mojich inscenáciú. V texte popri inom uvádza, že sa pre dej snažil vytvorit” „isté historické pozadie, ale nie dobovú repliku“". V scénografickej koncepcii to znamenalo biely puristický priestor s vol’ným proscéniom, poskytujúci adekvátne

\footnotetext{
${ }^{4}$ CONROY, C. Divadlo a telesnost'. Prel. J. Juráňová. Bratislava : Divadelný ústav, 2017, s. 28.

${ }^{5}$ ČANECKÝ, P. Cit a vedomie v kostýmovej tvorbe. In ŠTEFKO, V. (ed). Prednášky o divadle, s. 197.

${ }^{6}$ Tamže.

${ }^{7}$ Popri inscenácii Anna Kareninová píše R. Polák v texte habilitačnej prednáške aj o inscenáciách Mizantrop a Ivanov.

${ }^{8}$ POLÁK, R. Obsah a forma niektorých mojich inscenácii. In PAŠUTHOVÁ, Z. (ed.). Prednášky o divadle III., s. 73.
} 


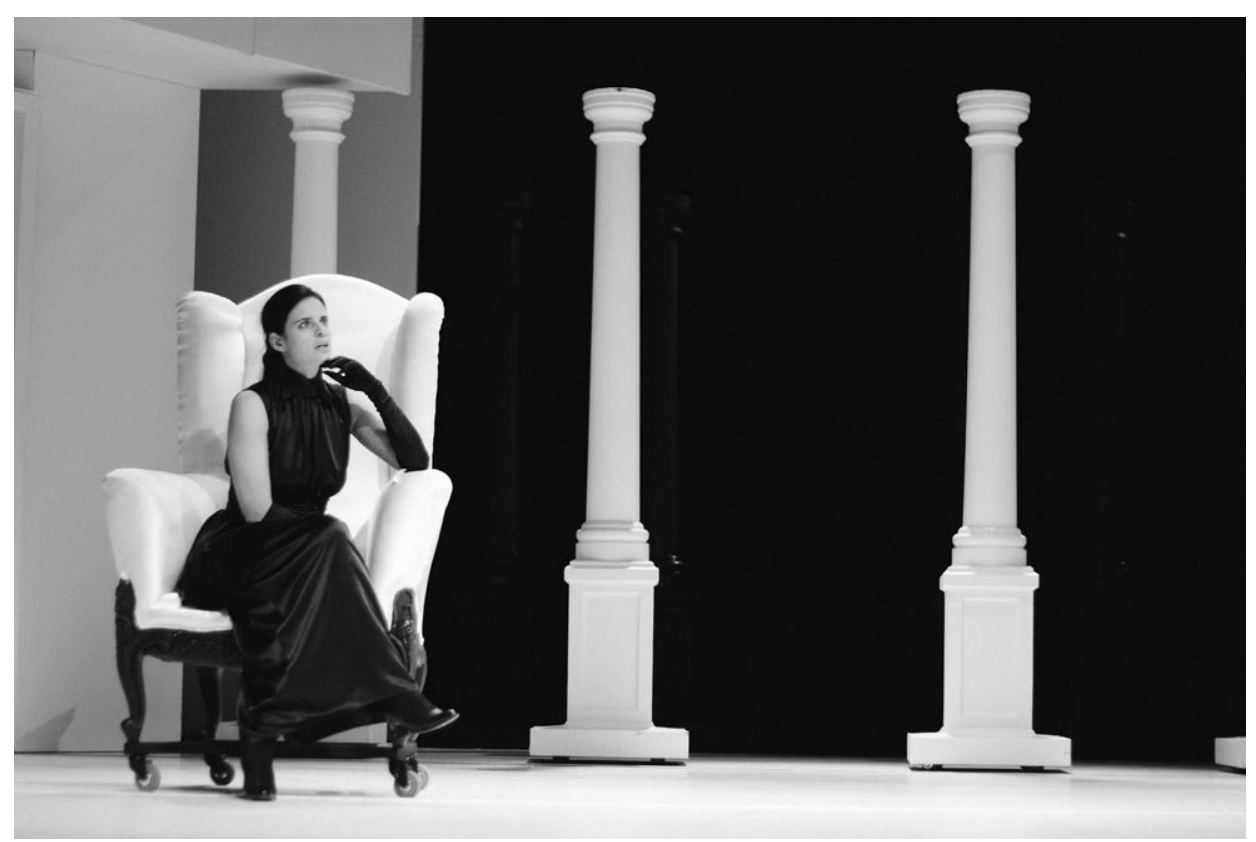

Lev Nikolajevič Tolstoj: Anna Kareninová. Slovenské národné divadlo, premiéra 13. 6. 2009. Réžia Roman Polák. Zuzana Fialová (Anna Kareninová). Foto archív Petra Čaneckého. Snímka Andrej Čanecký.

pozadie pre rozohratie kontrastu s kostýmami v achromatickom ladení. Požadovanú historickost’ zhmotnil Čanecký v kostýmovom riešení, vychádzajúcom podla Polákovho tvrdenia z „dobových znakov“" . Je ale dôležité všimnút si absentujúci kontext s odevnou kultúrou ruskej proveniencie, ktorá bola kompenzovaná vol’nou parafrázou módnych európskych vplyvov z konca 19. a začiatku 20. storočia. Podla teatrologičky Nadeždy Lindovskej, výtvarníkov zámer založený na využití achromatickej farebnosti pripomínal "svet čierno-bielych filmov ${ }^{\prime 10}$.

Kostým Anny Kareninovej je zaujímavé vnímat’ vo vztahu k alternujúcim interpretkám titulnej postavy, Zuzane Fialovej a Slávke Halčákovej. Hoci mal odev oboch predstaviteliek identické znaky, v dôsledku ich rozdielnych hereckých dispozícií a naturelu zobrazoval hlavnú hrdinku v rozdielnych polohách. Obe predstavitel'ky smerovali k vytvoreniu tragickej javiskovej postavy pozbavenej pátosu ${ }^{11}$, no ich diferencie boli jasne pozorovatelné v gestách a pohyboch, ale predovšetkým v komplexnej fyziognómii, ktorá je vo všeobecnosti určujúcim znakom pôsobiacim na heterogénne vnímanie. To, že Zuzana Fialová vyznela v javiskovom priestore rafinovane, bol nielen dôsledok používania jemne dekadentných, štylizovane teatrálnych póz a gest, ale najmä korelácie herečkinej siluety s Čaneckého výtvarným riešením kos-

\footnotetext{
${ }^{9}$ Tamže.

${ }^{10}$ Pozri LINDOVSKÁ, N. Štyri hodiny vo svete Anny K. In Monitoring divadiel na Slovensku, 12. 6. 2009. [online]. [cit. 10.2. 2018]. Dostupné na internete: https://www.monitoringdivadiel.sk/recenzie/recenzia/styrihodiny-vo-svete-anny-k/.

${ }^{11}$ Tamže.
} 


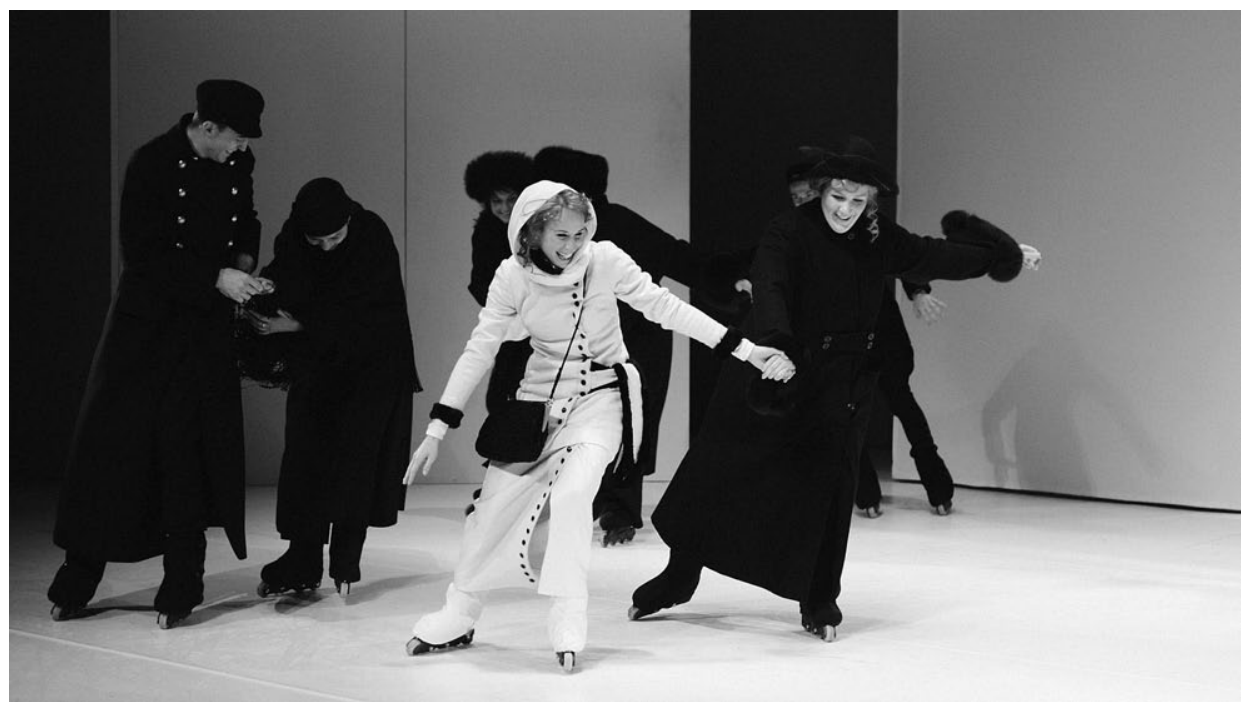

Lev Nikolajevič Tolstoj: Anna Kareninová. Slovenské národné divadlo, premiéra 13. 6. 2009. Réžia Roman Polák. V popredí Táňa Pauhofová (Kitty Ščerbacká). Foto archív Petra Čaneckého. Snímka Andrej Čanecký.

týmov. V porovnaní so Zuzanou Fialovou, Kareninová Slávky Halčákovej bola podla teatrologičky Nadeždy Lindovskej „, (...) mladou ženou 21. storočia. Odzrkadl'uje sa to $\mathrm{v}$ jej pohyboch aj v intonáciách reči. Je o niečo infantilnejšia a lyrickejšia. Ako manželka zaujíma voči Kareninovi skôr dcérsky postoj. Ako matka pôsobí nevyzreto. ${ }^{\prime \prime} 12$

Ďalším príkladom, na ktorom možno demonštrovat’ využívanie achromatickej farebnosti ako charakteristického atribútu poetiky Petra Čaneckého, je inscenácia hry Antona Pavloviča Čechova Višňový sad (Slovenské komorné divadlo Martin, 2017). Čaneckého kostýmová výprava podporila zámer režiséra Romana Poláka zobrazit’ na javisku mentálny rozpor medzi predstavitel'mi odchádzajúcej feudálnej generácie, ktorá nie je schopná reagovat’ na nové impulzy, a jej mladými nástupcami, ktorí už rozmýšlajú v duchu kapitalistickej morálky, neuznávajúc staré hodnoty. Na uvedenú skutočnost' upozornil teatrológ Karol Mišovic, podl’a ktorého je „konflikt dvoch antagonistických svetov“ sprítomnený práve v kostýmovom riešení Petra Čaneckého a líčení umeleckého maskéra Juraja Steinera: „(...) odeli postavy Ranevskej a jej spoločníkov do rokokových historických kostýmov a jediného zástupcu novej priebojnej generácie - podnikatel’a Lopachina - obliekli do súčasného semi-formal štýlu."13 Zobrazenie odchádzajúcej vysoko postavenej spoločnosti prostredníctvom rokokových variácií odevu vyznieva logicky, ked’že rokoko sa všeobecne vníma ako čas posledných pokusov o zachovanie feudalizmu. Dominantný sivý kolor, plošne zastúpený

12 Tamže.

${ }^{13}$ Pozri MIŠOVIC, K. Višňový svet ako panoptikálny svet kontrastov. In Monitoring divadiel na Slovensku, 18. 2. 2018. [online]. [cit. 10.3. 2018]. Dostupné na internete: https://www.monitoringdivadiel.sk/recenzie/ recenzia/visnovy-sad-ako-panoptikalny-svet-kontrastov/. 
v komplexnom achromatickom ladení rokokovo štylizovaných kostýmov, môžeme označit za relevantný znak vytvárajúci na pozadí abstraktnej scénografie ${ }^{14}$ obraz staroby, ktorá sa prevteluje do citov, vztahov a životných túžob postáv. Teatrologička Dagmar Inštitorisová vo svojej recenzii napísala: „Staroba Ranevskej nemá vek, má farbu. " ${ }^{15}$ Toto konštatovanie je signifikantné: autorka jasne pomenúva prítomný achromatizmus ako jeden $\mathrm{z}$ t’ažiskových elementov javiskového tvaru, $\mathrm{v}$ ktorom forma riešenia nasleduje tému a zároveň režijnú interpretáciu. Stretnutie dvoch rozdielnych svetov zintenzívnil Čanecký využitím súčasného civilného odevu pri postave Lopachina, ktorý v inscenácii zastupuje prichádzajúci kapitalizmus. Konfrontácia dvoch diferentných odevných kultúr v tomto prípade ozrejmuje funkciu kostýmu ako hlavného znakového činitel’a Polákovej inscenácie.

\section{Eliminácia}

Pri koncipovaní historických odevov Peter Čanecký často siaha po metódach abstrakcie a eliminácie. V inscenácii Piargy (SND, 2008), inšpirovanej prózou slovenských autorov naturizmu Františka Švantnera, Dobroslava Chrobáka a Margity Figuli, využil ako východiskovú platformu svojej koncepcie l’udový odev z oblasti Zliechova (okres Ilava). V rámci neho vylúčil signifikantné znaky týkajúce sa folklórneho dekoru (ozdobnosti), no pritom zachoval autentickost' strihov a prítomnost prírodného materiálu (l’an). Kostýmy v podobe eliminovaného l’udového odevu označovali spätost’ s dedinským prostredím Piargov, zároveň však prostredníctvom čierno-bielej farebnosti podporovali koncepciu abstraktne riešenej scénografie. ${ }^{16}$ Na rovnakú skutočnost’ reagoval divadelný estetik Miroslav Ballay, podla ktorého Čaneckého kostýmy „,korešpondujú s motívom každodennosti, pracovnými i sviatočnými odevmi dediny z medzivojnového obdobia“17. Recenzentka Mária Fekar Jenčíková metaforicky prirovnala hercov „,v nádherných l’anových kostýmoch Petra Čaneckého" k vášňam upleteným zo šúpolia. ${ }^{18}$ Popri vztahu k autentickosti kostýmov reflektuje toto konštatovanie aj správanie a konanie javiskových postáv, ktoré Polák v inscenácii mnohokrát zobrazil ako vášňami a túžbami zmietané subjekty.

Z hl'adiska spoločenských diferencií bol v kostýmoch k inscenácii Piargy zretel'ný kontrast medzi l'udovým a módnym dobovým odevom. Zatial' čo u prostých dedinčanov rešpektoval výtvarník špecifiká ludovej odevnej kultúry, pri vzdelanej vrstve ovplyvnenej vel'komestskou kultivovanostou siahol po odevoch sprítomňujúcich eleganciu danej doby. Pri mestskom odeve opät využil aj achromatickú farebnost'. Kostýmy popri prezentovaní príslušnosti ich nositel’ov k danej sociálnej skupine slúžili zároveň na podfarbenie vnútorného i vonkajšieho sveta inscenácie.

Princíp eliminácie použil Peter Čanecký aj pri riešení kostýmov k inscenácii opery Eugena Suchoňa Krútňava (Štátna opera v Banskej Bystrici, 2008). Výtvarník sa

\footnotetext{
${ }^{14}$ Prázdna scéna, ktorej na zadnom prospekte dominuje kovový rošt.

${ }^{15}$ INŠTITORISOVÁ, D. Staroba je sivá. In Pravda, 2017, roč. 27, č. 263, s. 33, 16. 11. 2017.

${ }^{16}$ Scénický výtvarník Jaroslav Valek vytvoril scénografickú koncepciu v čierno-bielom prevedení. Jej základom boli tri hranaté výsuvné portály, ktoré ohraničovali priestor, a pojazdné vysúvacie scény.

${ }^{17}$ Pozri BALLAY, M. Zasypané Piargy. In kød, 2008, roč. 2, č. 4, s. 10.

18 Pozri JENČÍKOVÁ FEKAR, Mária. Slovenská apokalypsa. In Monitoring divadiel na Slovensku, 18. 1. 2008. [online]. [cit. 11. 3. 2018]. Dostupné na internete: https://www.monitoringdivadiel.sk/recenzie/ recenzia/slovenska-apokalypsa/.
} 


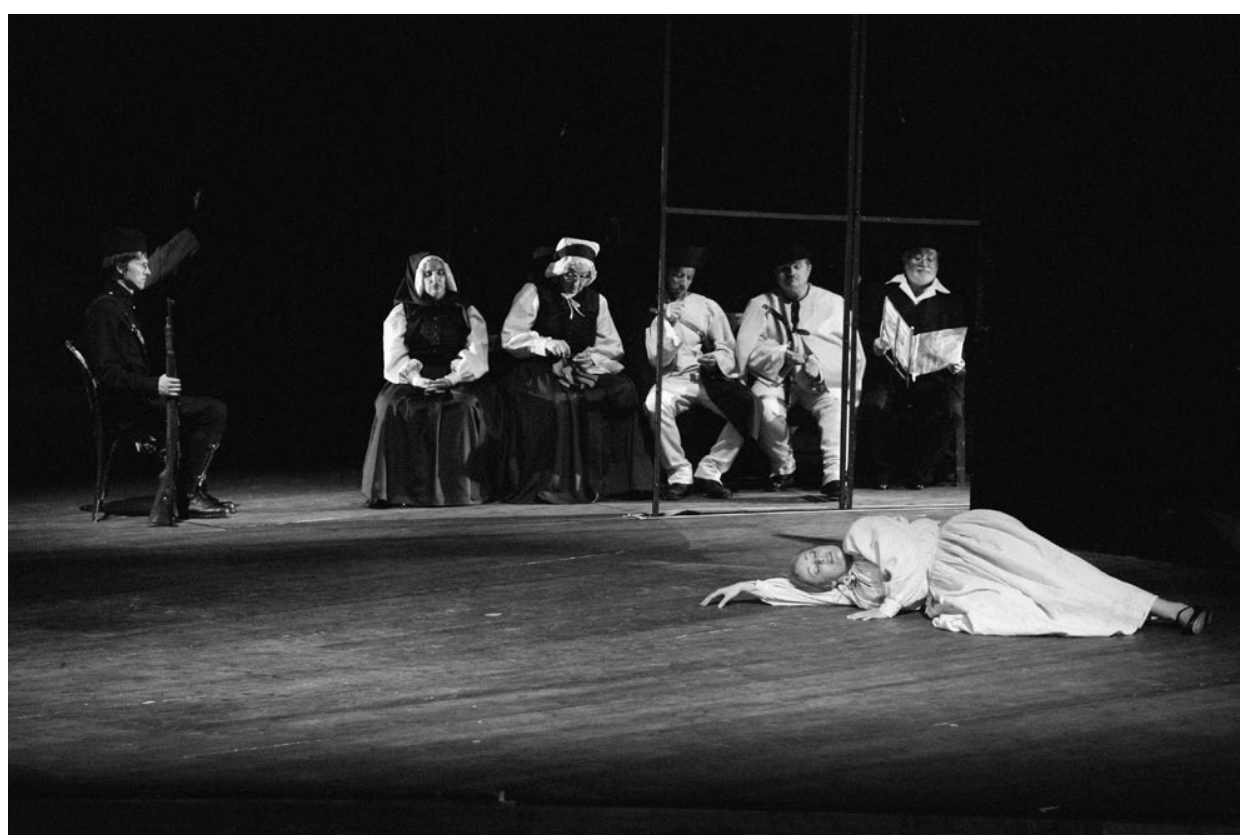

Eugen Suchoň: Krútňava. Štátna opera v Banskej Bystrici, premiéra 18. 10. 2008. Réžia Roman Polák. Karol Kurtulík (Žandár), Eva Lucká (Zalčíčka), Alena Hodálová (Školnica), Martin Popovič (Hríň), Peter Schneider (Krúpa), L’ubo Gregor (Dvojník). Vpredu Mária Porubčinová (Katrena). Foto Štátna opera. Snímka Jozef Lomnický.

naladil na výklad Romana Poláka, ktorý podla opernej kritičky Michaely Mojžišovej „zbavil dielo výtvarných ornamentov a režijne ho okresal až na špik kostí, obnažujúc rudimentárnu drámu l’udských vášní, uveritelných vztahov a autentických charakterov“19. Čanecký založil vizuál kostýmov na eliminácii folklórnych ornamentov, pričom ich farebnost’ zredukoval na bielu a čiernu. Túto abstrakciu pomenoval aj teatrológ a recenzent Ladislav Čavojský: „Peter Čanecký vyabstrahoval kostýmy z l'udových odevov. Ženy i chlapi sú bielom, ked’ sa menia na ,prízraky', halia sa kusom čierneho plátna. Je to čierna balada s bielymi figúrkami, kde-tu s červeným ozdobami sta kvapkami krvi.“20 Červenú farbu, vynímajúcu sa v kompozícií bielo-čiernych univerzalizovaných kostýmov, použil výtvarník v tretom obraze zobrazujúcom svadbu Katreny a Ondreja Zimoňa, ktorý muzikologička Mária Glocková nazvala „farebným bodom temnej inscenácie“21. Tretí obraz Suchoňovej opery sa dá z etnografického pohladu vnímat' ako pohlad do zvyklostí tradičných svadieb, no Roman Polák a jeho výtvarní spolupracovníci (popri Petrovi Čaneckom aj scénograf Jaroslav Valek) sa ani tu nenechali strhnút folklórnym koloritom.

${ }^{19}$ MOJŽIŠOVÁ, M. Suchoňova dráma okresaná na špik kosti. In $S M E, 2008$, roč. 16, č. 245, s. 18, 22. 10. 2008.

${ }_{20}$ ČAVOJSKÝ, L. Noc, temnôt prízraky, hodokvas pudov otupný. In Literárny dvojtýždenník, 2008, roč. 21 , č. $39-40$, s. 13, 18. 11. 2008.

${ }^{21}$ GLOCKOVÁ, M. Krútňava ako kameňolom osudov l’udí. In Hudobný život, 2008, roč. 40, č. 11, s. 25. 


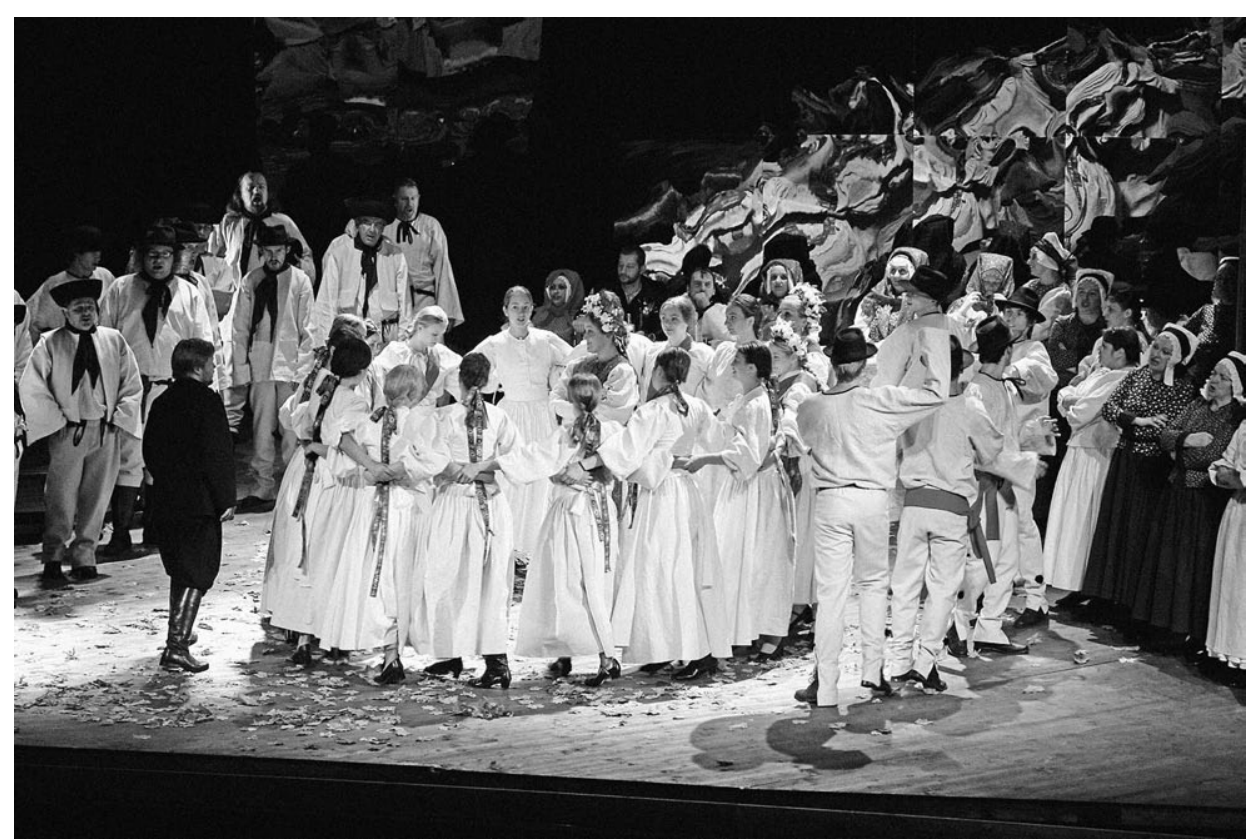

Eugen Suchoň: Krútňava. Štátna opera v Banskej Bystrici, premiéra 18. 10. 2008. Réžia Roman Polák. Svadobný obraz. Foto Štátna opera. Snímka Jozef Lomnický.

Ak by sme porovnávali spôsoby, akými Peter Čanecký koncipuje kostýmy v operných a činoherných inscenáciách, mohli by sme skonštatovat', že sú založené na identických princípoch, no v prípade opery je výtvarník ešte väčšmi než v činohre determinovaný nutnostou použit' vhodný odevný materiál. $\mathrm{K}$ tejto téme sa vyjadril aj vo svojej habilitačnej prednáške: „Nevedomé použitie nevhodných materiálov alebo ich nevhodné kombinácie môžu kostým na javisku diskvalifikovat'. Môže nevhodne šuštat', hrkotat', cinkat', či dokonca vŕzgat'. Prirodzene túto jeho možnú vlastnost' môžeme aj cielene využit'. "22

\section{Štylizácia}

Inscenácia hry Antona Pavloviča Ivanov (SKD Martin, 2006) prezentuje v poetike Petra Čaneckého typ výtvarnej koncepcie, kde sa štylizácia dosahuje prostredníctvom deformácie odevu. Kostýmové riešenie Ivanova pracovalo so súčasnými odevmi a opät využívalo čierno-bielu farebnost'. Postava Ivanova sa v Polákovom režijnom výklade nachádzala $\mathrm{v}$ tažkých depresívnych stavoch hraničiacich so psychózou a toto psychické rozpoloženie umocňovala i bipolárnost’ použitých achromatických farieb. Rovnaký kolor bol prítomný v scénografickej koncepcii Vladimíra Čápa. Režisér vniesol do scénického priestoru, pracujúceho o. i. s posuvnými paravánmi, antiiluzívny rozmer prezentovaný hercami divadla bunraku, ktorí vodili figurálne

${ }^{22}$ ČANECKÝ, P. Cit a vedomie v kostýmovej tvorbe. In ŠTEFKO, V. (ed). Prednášky o divadle, s. 197. 


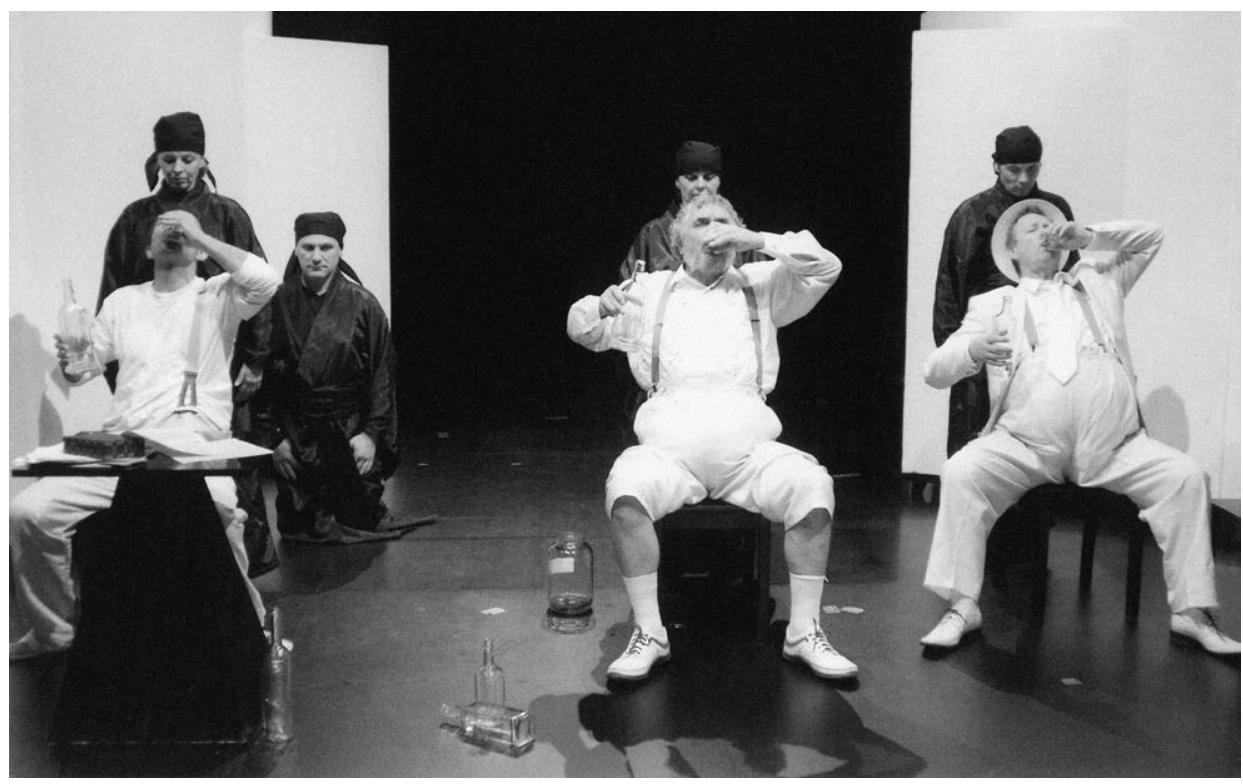

Anton Pavlovič Čechov: Ivanov. Slovenské komorné divadlo Martin, premiéra 19. 5. 2006. Réžia Roman Polák. František Výrostko (Michail Michailovič Borkin), Michal Gazdík (Pavel Kirilyč Lebedev), Ján Kožuch (Matvej Semionovič Šabel'skij). Foto Slovenské komorné divadlo. Snímka Branislav Konečný.

objekty s pohyblivými kíbmi (bábka malého chlapca, bábka starého muža a pod.). Deformačné anomálie boli prítomné u Zinaidy Savišnej (výrazne zväčšené prsia), aj u jej manžela Lebedeva a tiež Marfy Babakinovej (preexponované bruchá). Roman Polák sa vo svojej habilitačnej prednáške k tomuto riešeniu vyjadril, že „,(..) niekde vychádzajú z charakteristiky postáv, niekde bola deformácia takmer realistická“"23, pričom druhým prípadom bol gróf Šabel’skij so zhrbeným chrbtom. Režisérovi išlo predovšetkým o to, aby všetky postavy okolo hlavných protagonistov Ivanova, Sáry a Saši, predstavujúcich tragickú os inscenácie, niesli znaky typizácie či až karikatúry.

Štylizované anomálie vytvorené vypchatím častí tiel v oblasti brucha a hrudníka fungovali v rámci hereckých akcií ako funkčný nástroj a zároveň jeden z príznačných znakov v kontinuite interpretácie osudov postáv. Čanecký prostredníctvom štylizačných prostriedkov zachytil prelínanie znakov v realistickej a grotesknej rovine. Túto skutočnost’ reflektuje vo svojej štúdii aj teatrologička Dagmar Podmaková: „Výtvarné riešenie podčiarkovalo panoptikum karikatúry viac-menej sympatických l'udských osudov, dobra a zla, smiešneho a tragického, ktoré sa odráža v bábkach. “24 Telesné anomálie predurčovali postavy ku grotesknému správaniu, napríklad k vzájomným „bozkom“ prostredníctvom vypchatých častí.

${ }^{23}$ POLÁK, R. Obsah a forma niektorých mojich inscenácií. In PAŠUTHOVÁ, Z. (ed.). Prednášky o divadle III., s. 68.

${ }^{24}$ PODMAKOVÁ, D. Čechov v Polákovom videní. In KNOPOVÁ, E. (ed.). Divadelní režiséri na prelome tisícročí. Bratislava : Združenie slovenských divadelných kritikov a teoretikov a Ústav divadelnej a filmovej vedy, 2014, s. 121. 


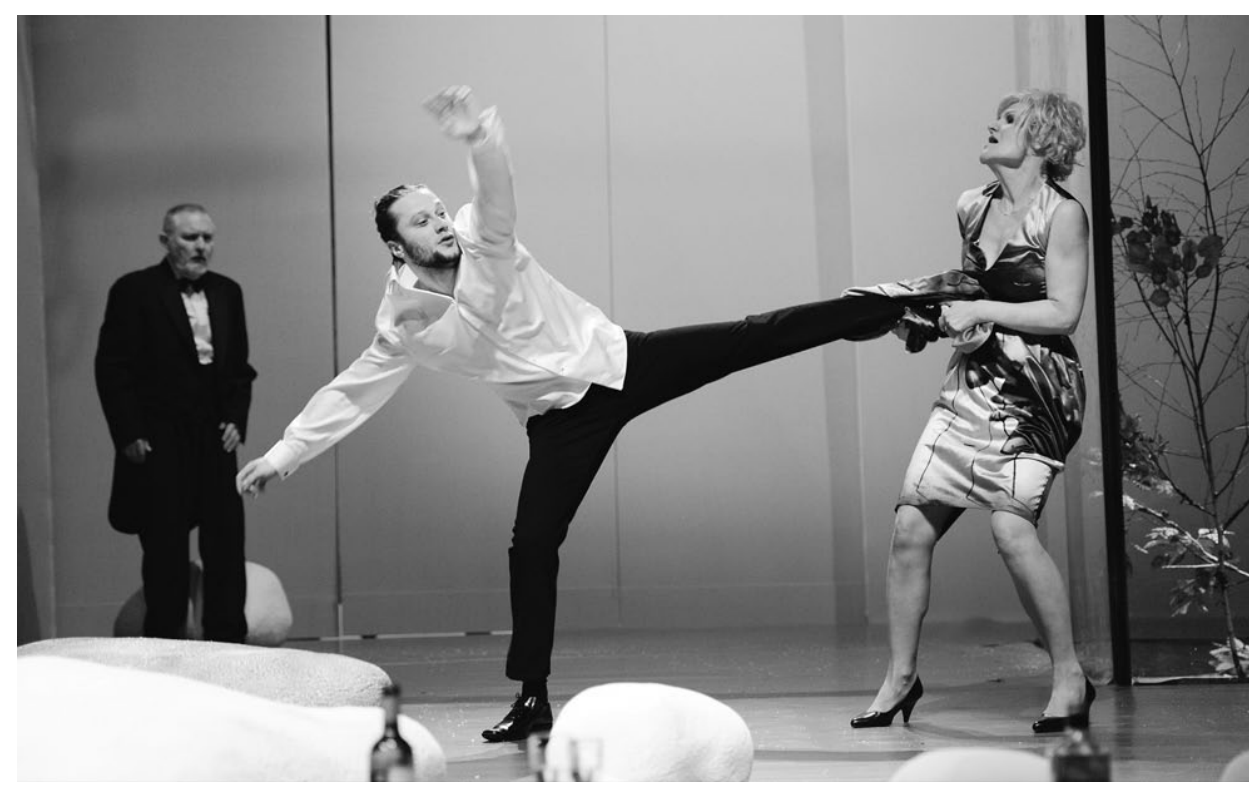

Molière: Mizantrop. Slovenské komorné divadlo Martin, premiéra 5. 2. 2010. Réžia Roman Polák. Viliam Hriadel (Bask), Marek Geišberg (Alcest), Jana Olhová (Arsinoé). Foto archív Petra Čaneckého. Snímka Branislav Konečný.

Inú formu štylizácie možno sledovat v kostýmovom riešení Molièrovej hry Mizantrop (SKD Martin, 2010), ktorá patrí do Polákovej „martinskej tetralógie“ ${ }^{“ 25}$. S Mizantropom sa režisér usiloval priniest' na javisko inscenačné dielo založené na kritickom pohlade na spoločnost $\mathrm{v}$ súčasnom disfunkčnom svete bez zábran. Túto tézu podkladá aj režisérovo vyjadrenie uverejnené v bulletine $\mathrm{k}$ inscenácii: „Celý súčasný svet je imitáciou. To pravé, skutočné môžeme nájsţ len vel’mi tažko $\mathrm{v}$ dnešnom virtuálnom svete, kde veci fungujú v akomsi umelom režime. Nájst dnes prirodzenost je vel'mi zložité. ${ }^{\prime 26}$

Polákova moralita predostrela svet vysokej spoločenskej vrstvy združenej „,v pluralite časov a prostredín ${ }^{\prime \prime 27}$ okolo Alcesta. Autonómnost’ spoločenstva Čanecký metaforicky stvárnil prostredníctvom kostýmov ušitých z textilných materiálov, na ktorých dominovali potlače slávnych expresionistických a surrealistických výtvarných diel. ${ }^{28}$ Kostýmy prostredníctvom extravagantných vzorov a strihov interpretovali svojich nositelov ako zvláštny homogénny kolektív vysokopostavených márnotratných ludí,

${ }^{25}$ Do „martinskej tetralógie“ popri Don(e) Juan(e) patrili inscenácie Striptíz Tartuffe (2003), Úbohý Lakomec (2003) a Mizantrop (2010).

${ }^{26}$ Rozhovor s režisérom Romanom Polákom, nielen o pripravovanej inscenácii. In Molière: Mizantrop. Programový bulletin. Martin : Slovenské komorné divadlo Martin. Zost. M. Michnová. Nestranované.

${ }^{27}$ Pozri ŠIMKOVÁ, S. Polákov Molière v 21. storočí. In PODMAKOVÁ, D. (ed.) a kolektív. Podoby a premeny hrdinu v súčasnom svete. Bratislava : Ústav divadelnej a filmovej vedy Slovenskej akadémie vied, 2011, s. 77.

${ }^{28}$ Bukolická krajina (Heinrich Campedonk), Portrét Alexandra Sacharoffa (Alexej von Jewlensky), Dáma v zelenom kabáte (August Macke), Džungl’a (Wifredo Lam), Vel'ká kompozícia (Jean Paul Riopelle) a iné. 


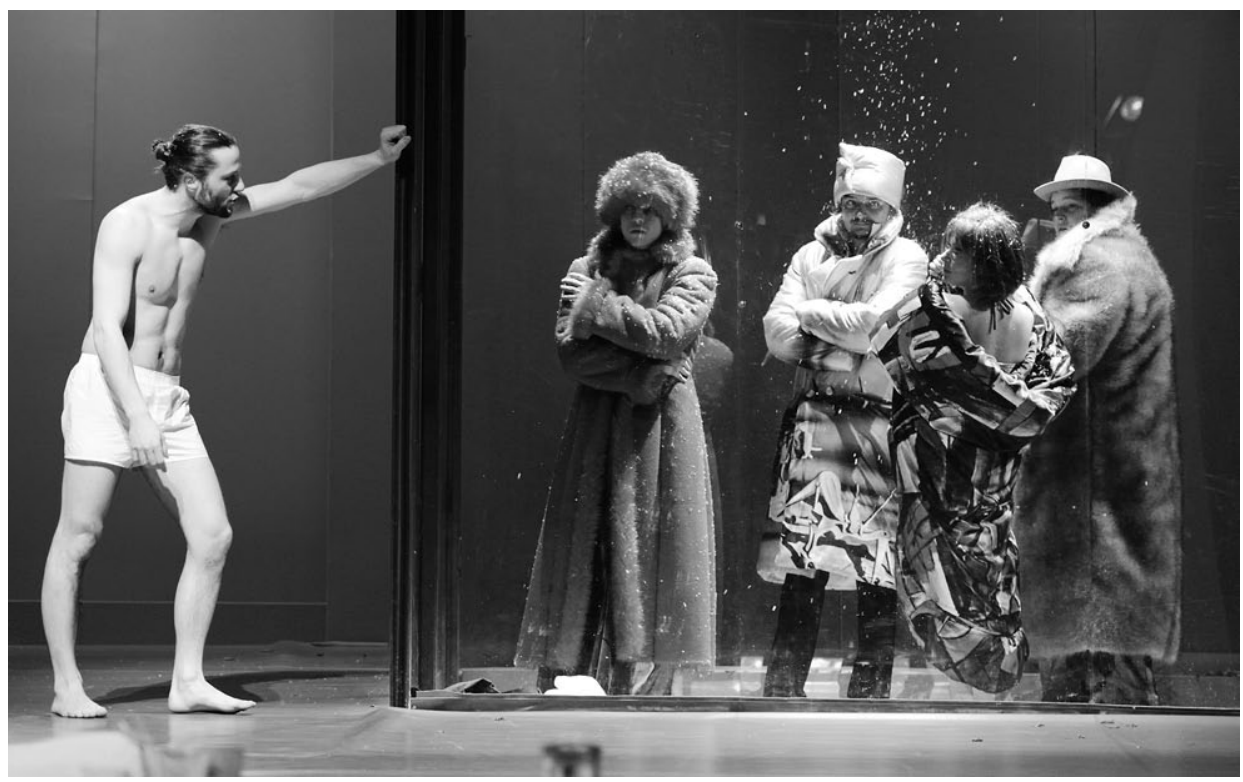

Molière: Mizantrop. Slovenské komorné divadlo Martin, premiéra 5. 2. 2010. Réžia Roman Polák. Marek Geišberg (Alcest), Nadežda Vladařová (Elianta), Daniel Heriban (Filint), Lucia Jašková (Celiména), Dominik Zaprihač (Klitander). Foto archív Petra Čaneckého. Snímka Branislav Konečný.

utápajúcich sa v mamone. Výtvarníkovu štylizovanú obraznost’ ozrejmuje aj Roman Polák v už citovanej habilitačnej prednáške, ked' poukazuje na krásu výtvarného dedičstva, ktoré súčasníci zdevalvovali na oblečenie. ${ }^{29}$ Teatrologička Soňa Šimková zase komentuje zapracovanie výtvarných reprodukcií v súvislosti s reprodukciami obrazov Gustáva Klimta na gýčových porcelánových servisoch. ${ }^{30}$ Ňou pomenovanú spojitosṫ nemožno v kontinuite s Caneckého štylizáciou považovat’ za náhodnú.

Postavy "odeté" do umeleckých diel prežívajú v simulovanom priestore plexisklového kubusu, do ktorého tvorcovia vložili znaky štyroch ročných období. Na javisku predvádzajú ustavičnú maškarádu nielen prostredníctvom pestrých, výstredných odevov, ale aj afektovaného správania či hereckého konania. Napríklad Celiména si zámerne oblieka župan poležiačky, ostentatívne vystavujúc polonahé telo Alcestovi a podobne. Ludí nachádzajúcich sa mimo tohto priestoru obliekol výtvarník do striedmych civilných odevov, kontrastných voči oblečeniu tých, čo žijú v kubuse: príroda a čas za plexisklom majú svoj vlastný systém, život mimo neho zase svoj. Opozitum voči kolektívu z kubusu predstavuje Alcest odetý v bielej košeli a čiernom trenčkote bez akýchkol'vek náznakov extravagancie. Ostáva individualitou odlišujúcou sa od farebne odetého davu, presne v duchu jednej zo svojich replík: „V tom zástupe chcem zostat’ odlíšený, sám, pretože ludským davom z duše

${ }^{29}$ POLÁK, R. Obsah a forma niektorých mojich inscenácií. In PAŠUTHOVÁ, Z. (ed). Prednášky o divadle III., s. 79.

${ }^{30}$ Pozri ŠIMKOVÁ, S. Polákov Molière v 21. storočí. In PODMAKOVÁ, D. (ed). a kolektív. Podoby a premeny hrdinu v súčasnom svete, s. 77. 


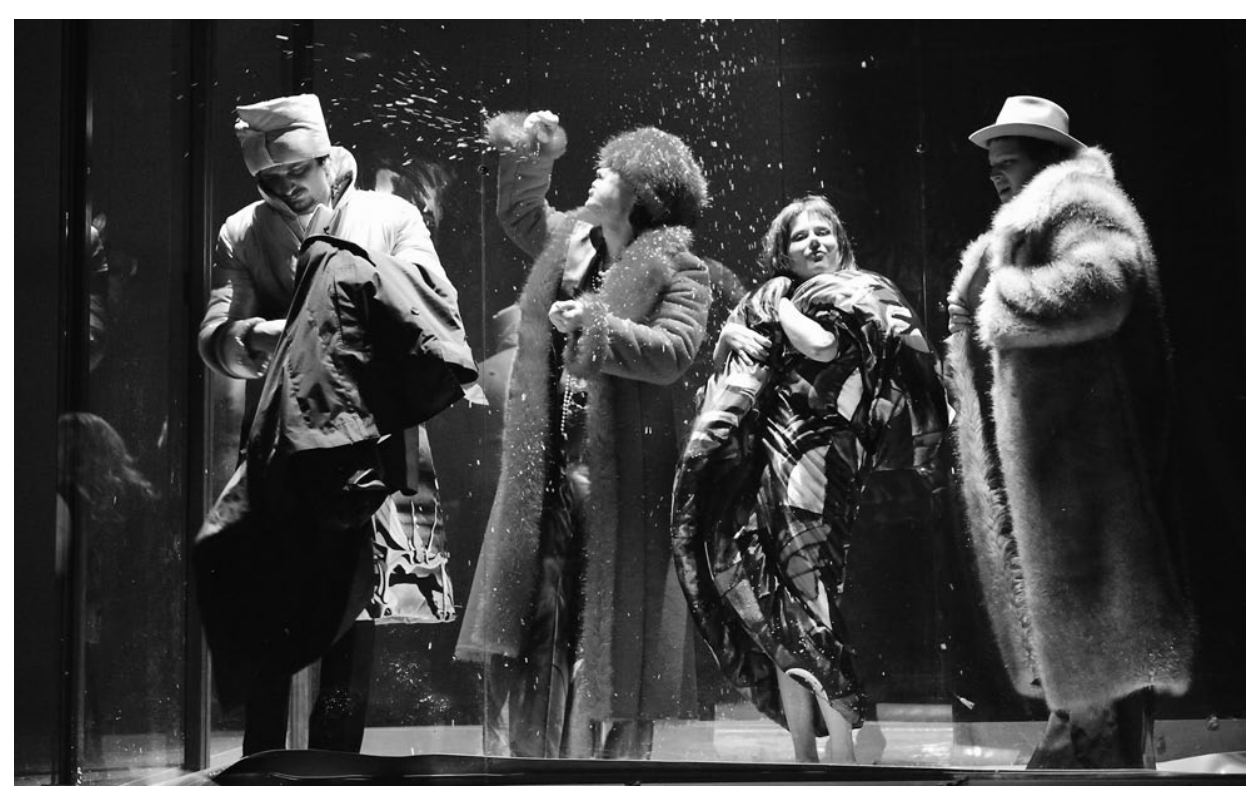

Molière: Mizantrop. Slovenské komorné divadlo Martin, premiéra 5. 2. 2010. Réžia Roman Polák. Daniel Heriban (Filint), Nadežda Vladařová (Elianta), Lucia Jašková (Celiména), Dominik Zaprihač (Klitander). Foto archív Petra Čaneckého. Snímka Branislav Konečný.

pohŕdam.“" ${ }^{31}$ Zatial' čo pre dav je charakteristické prežívat’ na javisku „permanentnú maškarádu, oblečením i správaním sa“32, postava Alcesta sa formálnym zobrazením prikláňa $\mathrm{k}$ prirodzenosti a autenticite.

Rozmanitost’ štylizačných prostriedkov Čanecký využil aj v jednom z predchádzajúcich molièrovských titulov "molièrovskej tetralógie“, v hre Don(a) Juan(a) (Divadlo Slovenského národného povstania Martin, 2001). Pozoruhodná inscenácia pracovala s radikálnou úpravou Molièrovho dramatického textu prostriedkami postmodernej palimpsestovej metódy. ${ }^{33}$ Polákova úprava spochybňuje stereotypné nazeranie na mužskú promiskuitnost'. Kladie si otázku, ako by to asi vyzeralo, ak by sa žena prevtelila do mužskej roly a v milostných vzt’ahoch si počínala ako muž. Polák vo svojom experimente nepozmenil iba pohlavie hlavného hrdinu, ale aj ostatných postáv, s výnimkou sluhov Sganarella a Gusmana, čím podl’a teatrologičky Soni Šimkovej vznikol „prevrátený obraz sveta, lebo dominantné mocenské pozície pripadli ženám, ako v mýtickom patriarcháte “34.

Takáto interpretácia umožnila kostýmovému výtvarníkovi uplatnit prvky štylizácie, ktoré viedli k zvýrazneniu dekadencie a bujarosti, čím výrazne podporili zá-

\footnotetext{
${ }^{31}$ MOLIÈRE. Mizantrop. Preložili V. Mihálik a Š. Povchanič. In Komédie III. Bratislava : Tatran, 1974, s. 11.

${ }^{32}$ ŠIMKOVÁ, S. Polákov Molière v 21. storočí. In PODMAKOVÁ, D. (ed). a kolektív. Podoby a premeny hrdinu v súčasnom svete, s. 80 .

${ }_{33}$ Tamže, s. 62.

${ }^{34}$ Tamže, s. 73.
} 


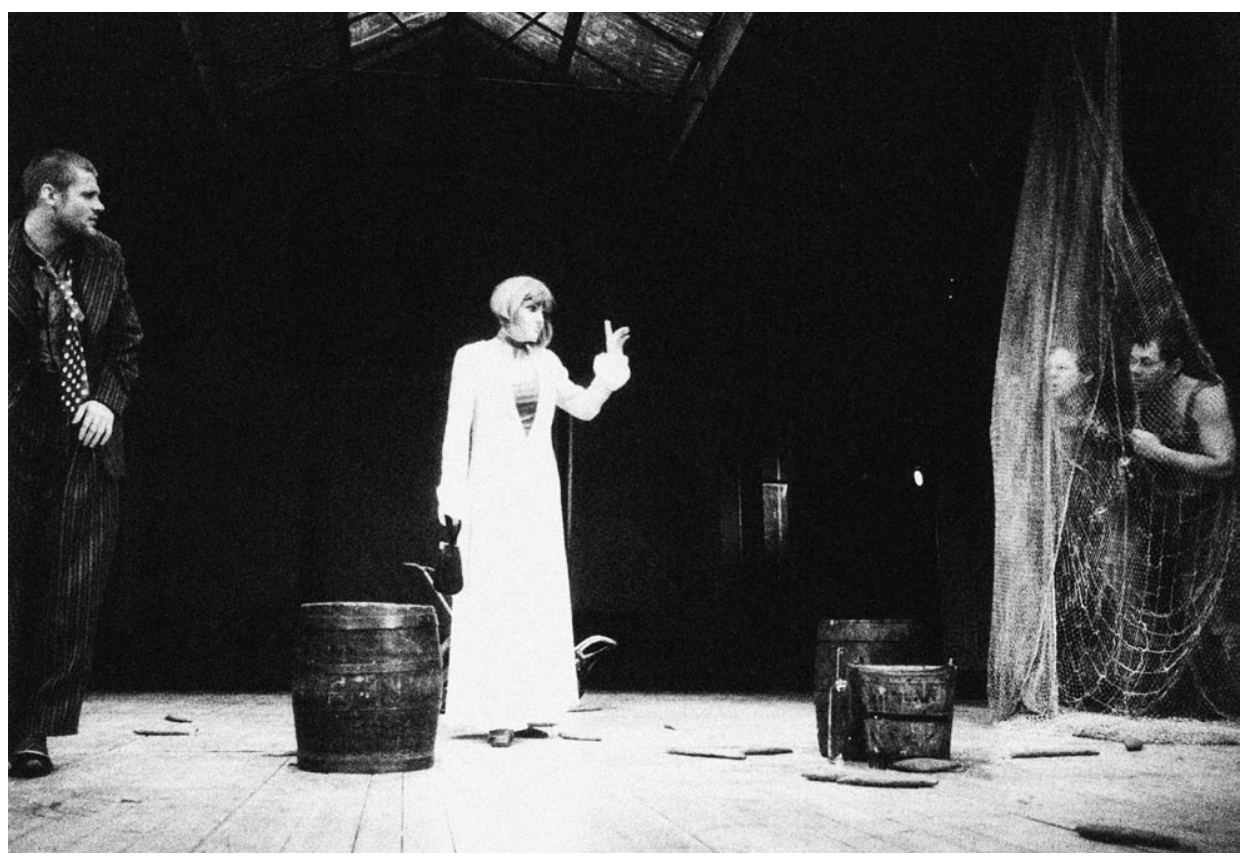

Molière - Roman Polák. Don(a) Juan(a). Divadlo Slovenského národného povstania Martin, premiéra 23. 3. 2001. Réžia Roman Polák. Milo Král' (Sganarelle), Jana Ol'hová (Doňa Juana), Michal Gazdík (Kato), František Výrostko (Charles). Foto Slovenské komorné divadlo Martin. Snímka Matúš Ol’ha.

mer vytvorit’ na javisku obraz frivolnej ženy s uzurpátorskými sklonmi a tendenciou k vulgárnosti. Postavu Done Juany, ktorú stvárnila Jana Olhová, zobrazil Peter Čanecký prostredníctvom rôznych odevných transformácií, v úzkom prepojení s herečkinou intonáciou, pohybom a jej komplexnou fyziognómiou. V prvej časti inscenácie obliekol Doňu Juanu do extravagantných šiat v štýle haute couture, zobrazujúc ju ako ženu-vampa a zároveň morálne upadajúcu bytost' (napr. bordová spoločenská róba doplnená štólou s tigrím motívom). Z dokumentácie k vzniku kostýmových návrhov je zrejmá Čaneckého inšpirácia tvorbou svetových módnych tvorcov Jeana Paula Gaultiera, Johna Galliana, Vivienne Westwood či Thierryho Muglera: citovaním módnych zdrojov došlo k zintenzívneniu výtvarného zobrazenia a posilneniu režijnej koncepcie. Medzi kostýmami Done Juany a jej ženskej družiny sú popri inom prítomné fetišistické úbory, formálne ovplyvnené Gaultierovou tvorbou, podporujúce vypätú sexualitu.

Druhá čast’ inscenácie odhalila postavu Done Juany v pomerne diferentnej polohe. Zatial' čo v prvej časti boli pre ňu do značnej miery príznačné galantné maniere a istý šarm, v druhej časti, po stretnutí s prízrakom Komtúrky, začali prevažovat’ sklony k agresívnemu správaniu, vonkajškovo sa prejavujúcemu pokrikovaním a grimasami. ${ }^{35}$ Túto zmenu štýlu reflektovali aj kostýmy Petra Čaneckého, prezentujúceho ústrednú protagonistku prostredníctvom minimalistických, v achromatickej

${ }^{35}$ Tamže, s. 74 . 
farebnosti komponovaných odevov s výrazne maskulínnymi znakmi. Čaneckého štylizácia vniesla prostredníctvom uvedených znakov do príbehu potrebnú frivolnost’ a dekadenciu a spolu so scénografickým riešením Petra Janků posilnila režijno-interpretačný zámer spočívajúci v snahe zobrazit’ prostredie Done Juany ako „brloh zvrátených činov“36.

\section{Záver}

Poetika kostýmového výtvarníka Petra Čaneckého prezentuje pomerne rôznorodú škálu invenčných prístupov a východísk. Za jeden z charakteristických, v tvorbe umelca dlhodobo udomácnených znakov možno považovat’ tendenciu $\mathrm{k}$ minimalistickému stvárneniu, ktorá súvisí najmä so štýlovou striedmostou zakotvenou v achromatickom kolore. Tento prístup analyzujeme v inscenáciách Anna Kareninová a Višňový sad. Minimalistické tendencie sa vo výtvarníkovej tvorbe pretavujú aj vo vizuálnej koncepcii historických a folklórnych kostýmov, kde je zjavná eliminácia dekoratívnych prvkov pri zachovaní autentických strihov: tento princíp sme demonštrovali na príklade inscenácií Piargy a Krútňava. Popri uvedených atribútoch identifikujeme v Caneckého výtvarnej poetike aj príklon k štylizácii, prostredníctvom ktorej sa snaží dosiahnut inovatívne významové konotácie, späté s konkrétnou režijnou interpretáciou. Tu nám ako argumentačná báza poslúžili - režisérom Romanom Polákom originálne a netradične interpretované - inscenácie Ivanov, Mizantrop a Don(a) Juan(a). Ked’že výtvarník Peter Čanecký vníma kostýmy v súvislosti s konkrétnymi predstavitel'mi, ich prirodzenou fyziognómiou a hereckým naturelom, v mnohých prípadoch sa v štúdii zaoberáme práve uvedenými kontextami. Snažíme sa poukázat' na dôležitost' kostýmu pri hereckej akcii, napríklad v kontinuite so stvárnením postavy Anny Kareninovej herečkou Zuzanou Fialovou či Don(y) Juan(y) v interpretácii Janou Ol'hovou.

\section{ON THE BASIC ATTRIBUTES OF PETER ČANECKÝ'S VISUAL POETICS, WITH A PARTICULAR FOCUS ON THE PRODUCTIONS DIRECTED BY ROMAN POLÁK}

\section{Nora NAGYOVÁ}

The study draws attention to the fundamental attributes of the poetics of Peter Čanecký, a prominent representative of Slovak costume design. The author concentrates on productions created in collaboration with her long-time colleague, director Roman Polák, and on a sample of concrete theatre titles she ventures to name and describe the basic features of Čaneckýs visual poetics.

\footnotetext{
${ }^{36}$ Tamže.
} 


\section{LITERATÚRA}

BALLAY, Miroslav. Zasypané Piargy. In kød, 2008, roč. 2, č. 4, s. 10. ISSN 1337-1800.

CONROY, Colette. Divadlo a telesnost'. Prel. Jana Juráňová. Bratislava : Divadelný ústav, 2017. 112 s. ISBN 978-80-8190-029-7.

ČANECKÝ, Peter. Cit a vedomie v kostýmovej tvorbe. In ŠTEFKO, Vladimír. Prednášky o divadle. Bratislava : Divadelný ústav a Vysoká škola múzických umení, 2004. 365 s. ISBN 80-88987-53-9.

ČAVOJSKÝ, Ladislav. Noc, temnôt prízraky, hodokvas pudov otupný. In Literárny dvojtýždenník, 2008, roč. 21, č. 39 - 40, s. 13, 18. 11. 2008. ISSN 0862-5999.

GLOCKOVÁ, Mária. Krútňava ako kameňolom osudov l'udí. In Hudobný život, 2008, roč. 40, č. 11, s. 25. ISSN 1335-4140.

INŠTITORISOVÁ, Dagmar. Staroba je sivá. In Pravda, 2017, roč. 27, č. 263, s. 33, 16. 11. 2017. ISSN 1335-4051.

JENČÍKOVÁ FEKAR, Mária. Slovenská apokalypsa. In Monitoring divadiel na Slovensku, 18. 1. 2008. [online]. Dostupné na internete: https://www.monitoringdivadiel.sk/recenzie/ recenzia/slovenska-apokalypsa/. ISSN 2454-00129.

LINDOVSKÁ, Nadežda: Štyri hodiny vo svete Anny K. In Monitoring divadiel na Slovensku, 12. 6. 2009 [online]. [cit. 10. 2. 2018]. Dostupné na internete: https://www.monitoringdivadiel.sk/recenzie/recenzia/styri-hodiny-vo-svete-anny-k/. ISSN 2454-0129.

MISTRÍK, Erich. Estetický slovník. Bratislava : Iris, 2007. 250 s. ISBN 978-80-89256-08-2.

MIŠOVIC, Karol. Višňový svet ako panoptikálny svet kontrastov. In Monitoring divadiel na Slovensku, 18. 2. 2018. [online]. [cit. 10. 3. 2018]. Dostupné na internete: https://www.monitoringdivadiel.sk/recenzie/recenzia/visnovy-sad-ako-panoptikalny-svet-kontrastov/. ISSN 2454-0129.

MOJŽIŠOVÁ, Michaela. Suchoňova dráma okresaná na špik kosti. In SME, 2008, roč. 16, č. 245, s. 18, 22. 10. 2008. ISSN 1335-4418.

MOLIÈRE. Mizantrop. In Komédie III. Prel. Vojtech Mihálik a Štefan Povchanič. Bratislava : Tatran, 1974. $309 \mathrm{~s}$.

PODMAKOVÁ, Dagmar. Čechov v Polákovom videní. In Divadelní režiséri na prelome tisícročí. Bratislava : Združenie slovenských divadelných kritikov a teoretikov a Ústav divadelnej a filmovej vedy SAV, 2014. 110 s. ISBN 978-80-969266-4-0.

POLÁK, Roman. Obsah a forma niektorých mojich inscenácií. In PAŠUTHOVÁ, Zdenka. Prednášky o divadle III. Bratislava : Vysoká škola múzických umení, 2016. 218 s. ISBN 9788089439980.

POLÁK, Roman. Rozhovor s režisérom Romanom Polákom, nielen o pripravovanej inscenácii. In Molière: Mizantrop. Programový bulletin. Martin : Slovenské komorné divadlo Martin. Zost. Monika Michnová. Nestranované.

ŠIMKOVÁ, Soňa. Polákov Molière v 21. storočí. In PODMAKOVÁ, Dagmar (ed.) a kolektív. Podoby a premeny hrdinu v súčasnom svete. Bratislava : Ústav divadelnej a filmovej vedy Slovenskej akadémie vied, 2011. 175 s. ISBN 978-80-967283-8-1. 